\title{
Sustainable Transport Indicators in the Context of Introducing of Electric Passenger Cars
}

\author{
Stevan Kjosevski*, Atanas Kochov, Darko Danev, Aleksandar Kostikj
}

\begin{abstract}
Sustainable development and sustainable transport are becoming of higher and higher importance. A scientific approach to sustainable development analysis means, first of all, identification of relevant indicators. Based on literature review and regional professionals' view, a total of 90 indicators have been chosen. They have been structured in five hierarchic levels. A total of five personal transport means alternatives have been analyzed in the research. The AHP method of analysis has been employed in which 75 professionals from the Western Balkan countries have filled appropriate questionnaire. The research presents their opinion about the capacity of each of the alternatives to contribute to the sustainable transport in the region, but also puts a light on perception of the professionals on importance of chosen indicators. The results of this research could be used for further research and could also help to decision making levels regarding sustainable transport and sustainable development.
\end{abstract}

Keywords: electric; indicators; sustainability; transport; vehicle

\section{INTRODUCTION}

Transport represents one of the biggest sectors of the global economy. It has strong impact on the three main pillars of sustainable development: Economy, Society and Environment.

Road transport is dominant part of the earth's transport. That is especially a fact when considering passenger transport in urban and extra urban areas.

Innovations and technology development lead to new transport means which are more acceptable in light of sustainable transport and development. The possibility of wider exploit of electricity for propulsion of road vehicles is an example of it. In parallel, plug-in hybrid and hybrid vehicles take their part on the market. Improvement and introducing other alternative fuel solutions should be added as well.

When, on different levels, decision about choice of transport means has to be taken, it will happen in complexity of a number of opposite aspects. That is especially the case when those decisions are policy related and therefore need to be in line with sustainable development principles.

In the last several decades the science has developed more methods which could help or substitute intuitive approach when taking decisions in such multi factorial conditions.

\section{SUSTAINABLE DEVELOPMENT}

Sustainable development attracts many institutions and authors to contribute to that process [1-3, 22]. Most of them consider that it should rely on the triple basis (three pillars) of the sustainability: Economy, Society, and Environment as shown in Fig. 1 [2].

United Nations pay special attention on global sustainable development mainly expressed by the Program for Sustainable Development which defines its 17 goals as shown in Fig. 2 [1].

Significant number of those goals are function of establishing sustainable transport [4-8]. Fig. 3 shows UN view of that correlation [4].
In order to drive transport towards its sustainability a number of issues need to be addressed [22]. All those aspects are not from the same nature, and not all of them are measurable, especially not in the same units. Also, not everyone has the same point of view and therefore uses different metrics on the same issue.

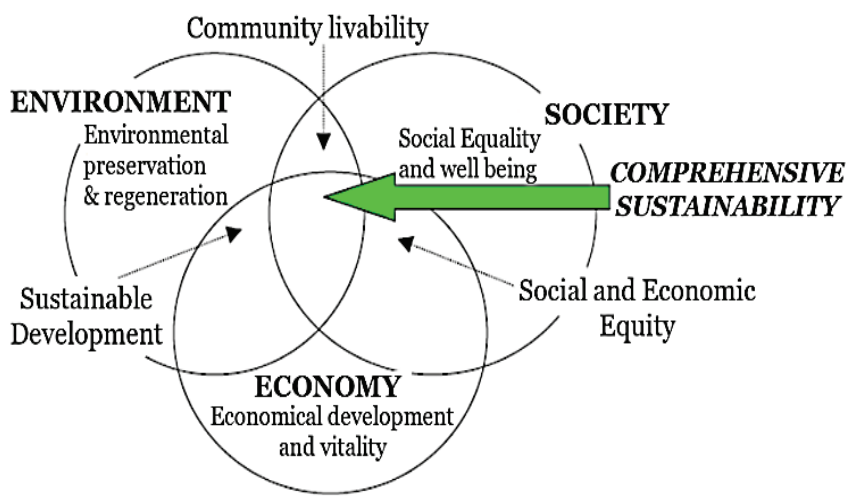

Figure 1 Sustainable development basis as defined on Ontario Round Table on Environment and Economy, 1991 [1]

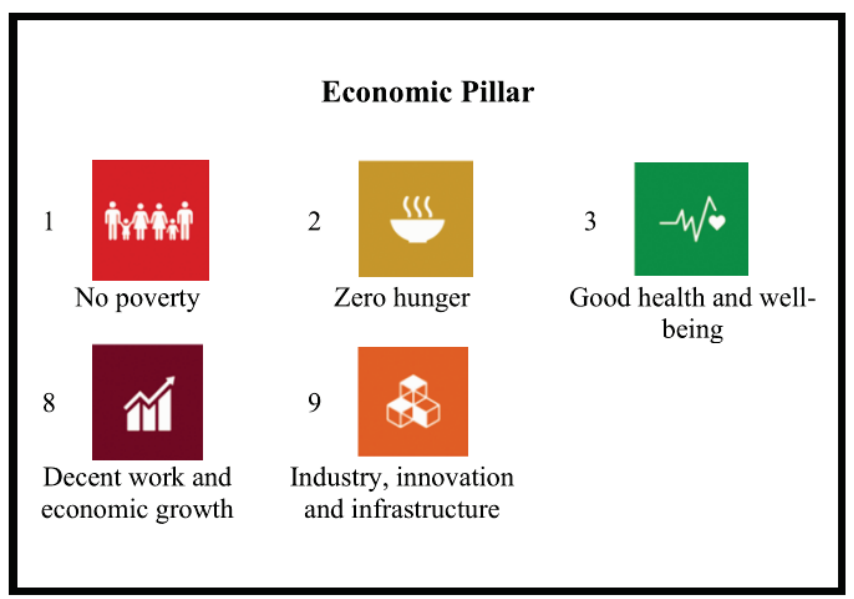

Figure 2 United Nations Sustainable Development Goals 


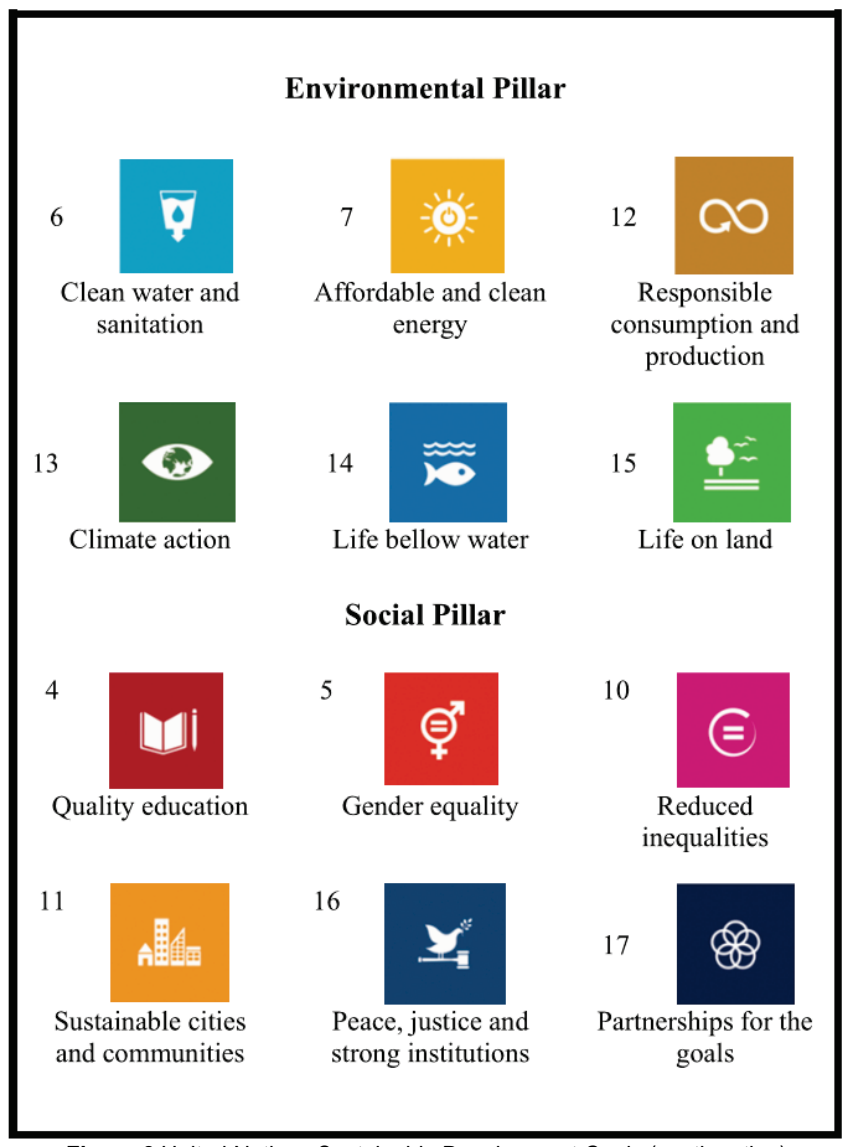

Figure 2 United Nations Sustainable Development Goals (continuation)

In the efforts to contribute to the sustainable development each decision needs to be made not only focused on specific interest, but in the context of sustainable development goals as much as possible. That should be especially the case when those decisions are related to the policy making. To do so, the process of decision making should be scientifically based.

Decision making methodologies cover important part of contemporary science [9-11].

Basically, decision making process is choosing one alternative from wider group, in systematic and logical manner. Main steps of such process are as follows: defining the problem in the core of decision making process; identifying the criteria; defining the alternatives; weighting each of the criteria; applying the criteria on each of the alternatives; applying rules for decision making; estimating the alternatives according to the criteria and identifying the best alternative.

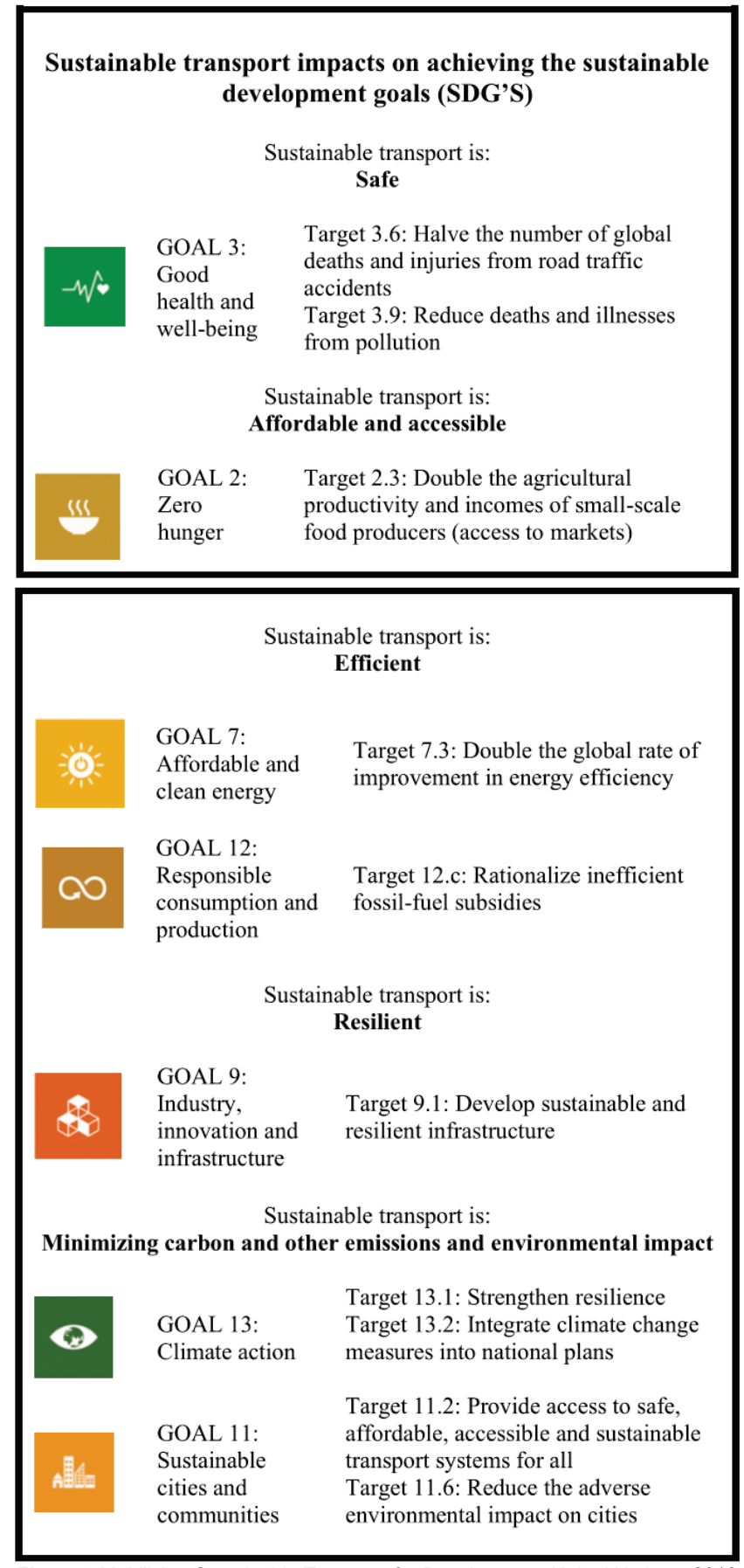

Figure 3 Mobilizing Sustainable Transport for Development; United Nations; 2016

\section{DEFINING THE PROBLEM AND RESEARCH APPROACH}

The wider research objective has been to clarify which alternatives of cars have most capacity of contribution to the sustainable transport and development, especially in the region of Western Balkan. The scientific approach to that objective included structuring and addressing most of the significant issues of sustainable transport. The almost unlimited area had to be analyzed by the tools of system engineering. In that respect, some general issues like fossil fuels availability, environmental aspects of electric energy production, energy and ecological aspects of production of 
different types of cars, their recyclability, and similar, have been taken out of the view. Also, the well-known fact that driving behavior can influence transport sustainability [23] has been considered constant, that is, it has not been identified as an indicator in this research.

The specific focus of the research described in this paper has been on identifying the most common indicators of sustainable transport, then perform scientifically based comparison on their importance in the context of described goal in similar developing countries, and earn experience which could be of help when there is decision making on different levels.

\subsection{Choosing of Research Methodology}

The literature [12], and the local experience point to the AHP methodology as a promising tool.

Besides choosing the alternative transport means, a rational choice of relevant indicators appeared to be one of the crucial factors for its efficiency and the quality of the results.

The variety of nature between the indicators, the way of their expression and possibilities of quantification, plus the different availability of data makes their choosing and processing quite complex. In some cases, the indicators could be well known quantities with measurable indexes of importance. Emission of gases and PM are an example, as well the car price and performances. On other hand, there are a number of indicators with complex nature, very hard to measure their indexes of influence, and in the same time with very different nature. The AHP research methodology in such cases employs view of experts through well-organized interview process.

\subsection{Identifying Indicators}

A number of literature sources deal with indicators related to sustainable transport [13-22]. Minimum number of indicators mentioned is eight, and maximum 87. Most of them fall in the standard pillars - economy, society, environment - but there are other areas as institutional, and so on. When talking about indicators related to electric vehicles, the number of literature sources is quite limited.

Having in mind the complexity of the area of sustainable transport, a rational choosing of the indicators with capacity to illustrate its relevant aspects presents one of the main issues [22].

In order to provide useable contribution to the area, this research has taken into account almost all available literature sources, and keeping a wide view, a list of 90 indicators has been defined to start the research with. This process has been supported by views of respectable experts interviewed.

All indicators are grouped in five hierarchy levels. The first level consists of the main pillars, in this case: economy, society, environment, good governance and planning and culture. Tab. 1 shows all indicators with their level in the hierarchy.
Table 1 Indicators with their hierarchy level

\begin{tabular}{|c|c|}
\hline & Hierarchy level indicator \\
\hline \multirow{3}{*}{ 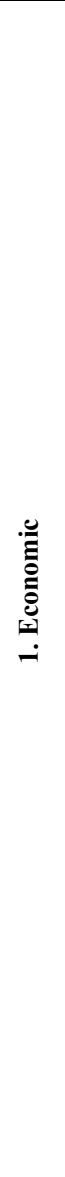 } & $\begin{array}{l}\text { 2. Transport Demand and Intensity } \\
\text { 3. Volume of transport relative to GDP } \\
\text { 3. Vehicle prices relative to GDP } \\
\text { 4. Average registered car value (vs GDP) } \\
\text { 4. Vehicles per } 1000 \text { population } \\
\text { 4. Newly registered cars } \\
\text { 5. New cars price } \\
\text { 5. Used cars price } \\
\text { 3. Volume of transport (passenger-km) } \\
\text { 4. Public } \\
\text { 4. Personal } \\
\text { 5. Taxi } \\
\text { 5. Private car } \\
\text { 3. Transport performances } \\
\text { 4. Range } \\
\text { 4. Dynamic performances }\end{array}$ \\
\hline & $\begin{array}{l}\text { 2. Infrastructure } \\
\text { 3. Local road length per capita } \\
\text { 3. Density local road infrastructure }\left(\mathrm{km}-\mathrm{km}^{2}\right) \\
\text { 3. Parking spaces } \\
\text { 4. Public parking spaces } \\
\text { 5. With electric charging facility } \\
\text { 5. Without electric charging facility } \\
\text { 4. Residential parking spaces } \\
\text { 5. With electric charging facility } \\
\text { 5. Without electric charging facility }\end{array}$ \\
\hline & $\begin{array}{l}\text { 2. Transport Costs and Prices } \\
\text { 3. Expenses for vehicles usage } \\
\text { 4. Environmental taxes } \\
\text { 4. Expenditures/taxes on roads, parking, etc. } \\
\text { 3. Motor vehicle fuel prices and taxes } \\
\text { 4. Fuel/electricity prices } \\
\text { 4. Fuel/electricity tax rates } \\
\text { 3. Capital maintenance costs } \\
\text { 4. Capital maintenance cost/new vehicle price ratio } \\
\text { 4. Frequency of capital maintenance cost }\end{array}$ \\
\hline \multirow{3}{*}{ 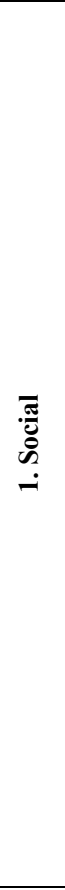 } & $\begin{array}{l}\text { 2. Accessibility and Mobility } \\
\text { 3. Personal mobility (daily or annual person-km and trips } \\
\text { by income group) } \\
\text { 4. Average passenger journey time } \\
\text { 4. Average passenger journey length } \\
\text { 4. No. of journeys } \\
\text { 4. Total time spent in traffic } \\
\text { 3. Volume of passengers } \\
\text { 3. Adaptability for people with disabilities (possibility for } \\
\text { control by people with disabilities) }\end{array}$ \\
\hline & $\begin{array}{l}\text { 2. Affordability } \\
\text { 3. Private car ownership } \\
\text { 3. Average household expenditure } \\
\text { 3. Share of transport cost from total household expenditure }\end{array}$ \\
\hline & $\begin{array}{l}\text { 2. Safety and Health } \\
\text { 3. Cases of chronic respiratory diseases, cancer, headaches. } \\
\text { Respiratory restricted activity days and premature } \\
\text { deaths due to motor vehicle } \\
\text { 4. Exposure to particulate matter (PM), nitrogen dioxide } \\
\text { (NO2), carbon monoxide (CO); } \\
\text { 4. Respiratory diseases due to vehicular pollutants (affected } \\
\text { per } 1000 \text { population) } \\
\text { 3. Population exposed to and annoyed by traffic noise, by } \\
\text { noise category and by mode associated with health and } \\
\text { other effects. } \\
\text { 4. Traffic noise levels } \\
\text { 4. Hearing impairment due to traffic noise }\end{array}$ \\
\hline 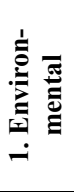 & $\begin{array}{l}\text { 2. Car Emissions } \\
\text { 3. Particulates emissions } \\
\text { 4. Particulates (mass) } \\
\text { 4. Particulates (number) } \\
\text { 3. NOx emissions } \\
\text { 3. CO emission }\end{array}$ \\
\hline
\end{tabular}




\begin{tabular}{|c|c|}
\hline & $\begin{array}{l}\text { 2. Technology Level } \\
\text { 3. Proportion of vehicle fleet meeting certain air emission } \\
\text { standards } \\
\text { 4. Euro } 5 \text { or higher } \\
\text { 4. Euro } 4 \text { or lower } \\
\text { 4. Electric or Plug-In Hybrid } \\
\text { 3. Average age of vehicle fleet }\end{array}$ \\
\hline & $\begin{array}{l}\text { 2. Impacts on Environmental Resources } \\
\text { 3. Habitat and ecosystem disruption } \\
\text { 4. Climate Change } \\
\text { 4. Damage to ecosystems } \\
\text { 3. Energy efficiency } \\
\text { 3. Renewables } \\
\text { 4. Use of renewable energy sources in current fleet } \\
\text { 4. Use of renewable energy sources in first registered } \\
\text { vehicles } \\
\text { 3. Transport energy consumption per capita } \\
\text { 4. Use of non-renewable resources and energy } \\
\text { 4. Use of renewable resources and energy }\end{array}$ \\
\hline 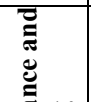 & $\begin{array}{l}\text { 2. Measures to Improve Transport Sustainability } \\
\text { 3. R\&D expenditure on "eco vehicles" and clean transport fuels } \\
\text { 3. Total expenditure on pollution prevention and clean-up }\end{array}$ \\
\hline 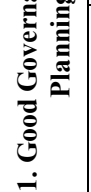 & $\begin{array}{l}\text { 2. Strategic plan for reduction of transport impact on the } \\
\text { environment and population health } \\
\text { 3. Implementation of measures to reduce transport impact in } \\
\text { regard to municipality strategic documents } \\
\text { 3. Strategic planning of public transport with electric vehicles }\end{array}$ \\
\hline ن & \\
\hline $\begin{array}{ll}\text { Rema } \\
- & \mathrm{Tl} \\
- & \mathrm{Tl} \\
- & \mathrm{Tl} \\
& \mathrm{le} \\
- & \mathrm{In} \\
\end{array}$ & $\begin{array}{l}\text { ns: } \\
\text { number in front of the indicator shows its hierarchy level. } \\
\text { first column contains only the indicators on first hierarchy level. } \\
\text { second column shows indicators on second, third, fourth and fifth } \\
\text { icators having sub indicators on lower level are bold. }\end{array}$ \\
\hline
\end{tabular}

The indicator "Cultural" is quite new in terms of mentioning and has very broad meaning. It is still needed to get further clarification and subdivision. Therefore, in this research it is put on hierarchic level 1 without further expansion. The aim was to obtain "the first view" of interviewed professionals as starting information for potential future focus on that aspect.

\subsection{Selection of Alternatives}

Based on the market development, the following alternatives of vehicles have been chosen: A1 - electric; A2 plug-in hybrid; A3 - hybrid; A4 - car with ICE with alternative fuel (gas or similar); A5 - car with petrol ICE, and A6 - car with diesel ICE.

\subsection{Research Activities, Processing, Analysis and Presentation of the Results}

In all cases where quantitative data were available, indicators have been compared (in pairs) based on them. For the rest of the indicators, the AHP method has been employed by filling of previously prepared questionnaires by experts in the area under research. All Western Balkan countries have been covered in the process.
Tab. 2 shows the structure of the experts interviewed by the countries they live and work.

Table 2 Structure of the experts interviewed by countries

\begin{tabular}{|c|c|c|c|c|c|c|c|}
\hline Country & MK & RS & BIH & ME & AL & XK & WB \\
\hline Participant number & 31 & 9 & 9 & 6 & 10 & 8 & 73 \\
\hline
\end{tabular}

Tab. 3 shows the structure of the experts by the area of their profession.

\begin{tabular}{|c|c|c|c|c|}
\hline & Academic & Business & $\begin{array}{l}\text { Governmental and } \\
\text { non-governmental }\end{array}$ & Total \\
\hline Western Balkan & 29 & 27 & 17 & 73 \\
\hline
\end{tabular}

\section{RESULTS}

Being processed by professional software for AHP methodology, results offer a variety of possibilities for analysis and presentation. This has been used for analysis of the sensitivity of results depending on the country, professional profiles, and number of different aspects. Finally, the consistence of different indicators influence shows their relevance to the subject analyzed.

With high number of indicators and used hierarchy research methodology (AHP) a very rich list of results has been achieved. In this paper, only the results gathered on first hierarchic level will be presented and discussed.

Fig. 4 shows influence of different indicator groups on first hierarchic level for Western Balkan and separate countries.

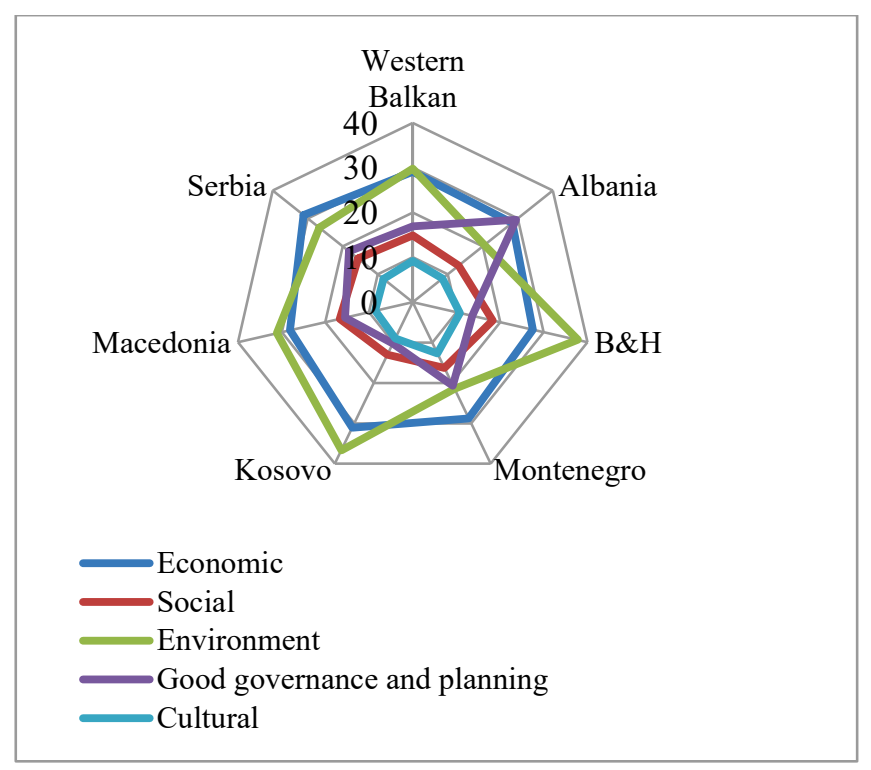

Figure 4 Influence of different indicator groups on the first hierarchic level for Western Balkan and separate countries.

Fig. 5 shows influence of different indicator groups on the first hierarchic level for Western Balkan and different expert profiles. 


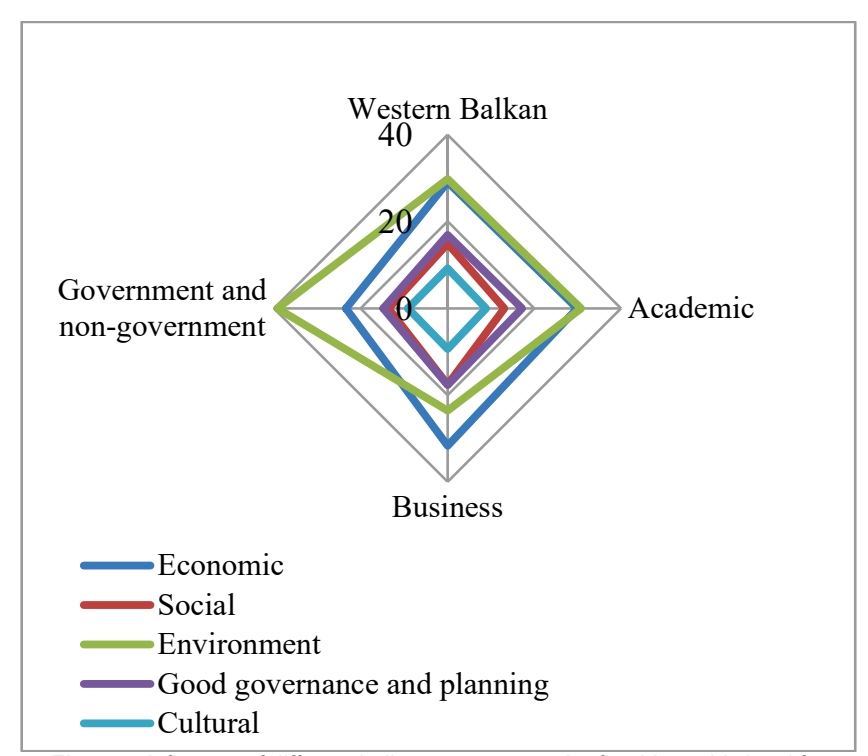

Figure $\mathbf{5}$ Influence of different indicator groups on the first hierarchic level for Western Balkan and different expert profiles

Fig. 6 shows the results of different alternative vehicles in the context of their capacity to contribute to sustainable development for whole Western Balkan and separate countries.

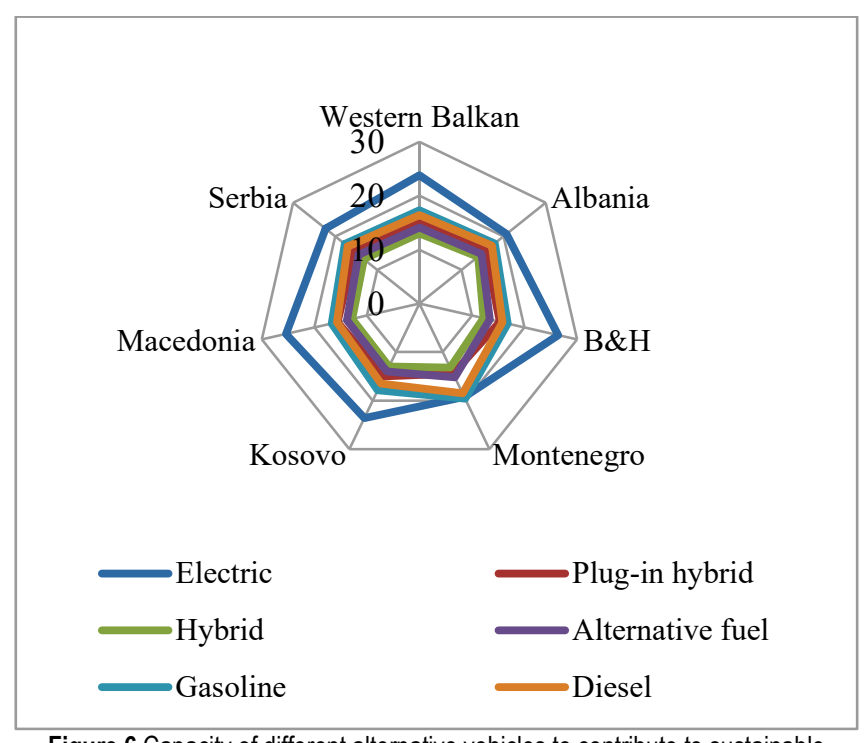

Figure 6 Capacity of different alternative vehicles to contribute to sustainable development

Fig. 7 shows the results of different alternative vehicles in the context of their capacity to contribute to sustainable development based on results of interviews of different profiles of experts.

There are general conclusions to be drawn, which are valid for each country and each group of professionals.

First, it is obvious that the relatively new group of indicators "Cultural" scores very low importance (Fig. 4 and Fig. 5) and so far, it could be neglected, while some of its aspects (indicators) could be moved in other pillars (like "social").
Due to the fact that Social, and Good Governance and Planning pillars generally score similar results (Fig. 4 and Fig. 5), another simplification in further analyses could include mixing parts of their sub indicators.

On the other hand, in Good Governance and Planning, fairly new group of indicators make some differences in different countries. It is superior, together with economy indicators for Albania (Fig. 4), and is second best, together with ecological group of indicators for Montenegro (Fig. 4). Therefore, further research focusing on these aspects might be helpful.

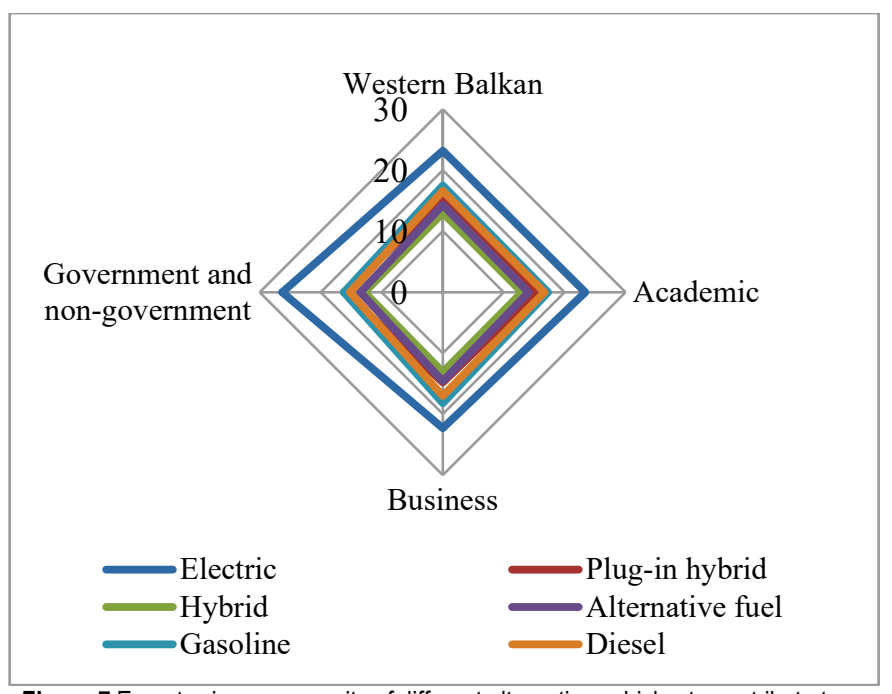

Figure 7 Experts view on capacity of different alternative vehicles to contribute to sustainable development

Analysis of the results in Fig. 4 in general shows that experts from all countries consider economic and environmental indicators superior. Still, there are more details to be taken into consideration from these results. While the economic group of indicators has high scores in all countries, the environmental group shows interesting differences between them.

Countries with heavy environmental problems consider ecology more important than economy and those with minor ecology problems emphasize importance of the economy. Bosnia and Herzegovina, Kosovo and North Macedonia consider the environmental group of indicators as most important, while the same group has much lower importance for Albania and Montenegro.

The correlation of these results with well-known pollution statistics separate Western Balkan countries. Bosnia and Herzegovina, Kosovo and North Macedonia especially in their biggest cities suffer heavily of pollution problems. On other hand, Montenegro and Albania are the only analyzed countries with exit to the sea which obviously has an influence on reducing the pollution. Those differences have clear correlation with the results achieved by this research (Fig. 4).

In the eyes of the experts another picture is drawn (Fig. 5). In comparison to the academic profiles who consider economy and ecology equally important, business professionals prefer economy indicators, and those working 
in governmental and non-governmental institutions consider ecology aspects more important than those belonging to the economy pillar.

Fig. 6 and Fig. 7 show the results regarding the vehicle alternatives in terms of their capacity to contribute to the sustainable transport and development as a whole. Since this paper is focused on explaining the indicators, and not the alternatives, Fig. 6 and Fig. 7 should be considered informative only.

\section{CONCLUSION}

In similar countries, as the countries of Western Balkan are, the results of the research show high consistency. That has been proven by the used research method (AHP).

Having in mind the results of the research and the goals of sustainable development, it is obvious that in order to make decisions in the area of transport which have most promising results in the context of sustainable development, there is a need of wider approach both regionally and professionally.

Also, if some decisions have to be made in narrow area (personal, family, company, urban, extra urban), it is normal to expect that not all indicators would be taken into consideration. These decisions could not be considered as fully oriented towards sustainable transport and development.

Therefore, it is up to the people who work on the level of policy-making to take appropriate decisions which will create conditions that will turn the transport towards the direction of sustainable development. That means those decisions will steer other people who have more narrow interest in the end to take decisions generally in line with the process of sustainable development. Most of these tools lie in the economic pillar of indicators.

In all cases of decision making, there is a possibility to define much shorter list of indicators than the ones used in the actual research, and still achieve reliable results in the process of decision making.

\section{Notice}

The paper will be presented at MOTSP 2020 International Conference Management of Technology - Step to Sustainable Production, which will take place from $30^{\text {th }}$ September $-2^{\text {nd }}$ October 2020 in Bol, island Brač (Croatia). The paper will not be published anywhere else.

\section{REFERENCES}

[1] United Nations. (2015). Transforming our World: The 2030 Agenda for Sustainable Development, United Nations. https://sustainabledevelopment.un.org/post2015/transforming ourworld/

[2] The Centre for Sustainable Transportation. (2002). Definition and vision of sustainable transportation; Mississauga, Canada.

[3] Emas, R. (2015). The Concept of Sustainable Development: Definition and Defining Principles. Brief for GSDR 2015.
[4] Secretary-General's High-Level Advisory Group on Sustainable Transport. (2016). Mobilizing Sustainable Transport for Development, United Nations.

[5] Black, W. R. (2004). Sustainable Transport: Definitions and Responses. TRB/NRC Symposium on Sustainable Transportation Baltimore, MD July 12, 2004.

[6] CH2M HILL and Good Company. (2009). Transportation and Sustainability - Best Practices Background. Sustainability Peer Exchange - Centre for Environmental Excellence by AASHTO, May 27-29, 2009.

https://environment.transportation.org/pdf/sustainability_peer _exchange/AASHTO_SustPeerExh_BriefingPaper.pdf

[7] Commission Expert Group on Transport and Environment. (2000). Defining Environmentally Sustainable Transport System, European Commission. http://www.seedengr.com/ Defining\%20an\%20Environmentally\%20Sustainable\%20Tra nsport $\% 20$ System.pdf

[8] Kong, D. \& Baptista, M. (1999). Sustainable Transportation in the $21^{\text {st }}$ Century, Cyber Press, Santa Clara, California Mineta Transportation Institute, https://transweb.sjsu.edu/sites/ default/files/pdfs/MTI_TeacherGuide.pdf

[9] Fülöp, J. (2016). Introduction to Decision Making Methods. Laboratory of Operations Research and Decision Systems, Computer and Automation Institute, Hungarian Academy of Sciences. https://www.slideshare.net/ghaiath/ introduction-todecision-making-methods

[10] Barfod, M. B. \& Leleur, S. (2014). Multi-criteria decision analysis for use in transport decision making. Technical University of Denmark, Transport. https://backend.orbit.dtu.dk/ws/portalfiles/portal/104276012/ DTU_Transport_Compendium_Part_2_MCDA_pdf

[11] Velasquez, M. \& Hester, P. (2013). An analysis of multicriteria decision making methods. International Journal of Operations Research, 10. 56-66.

[12] Buzási, A. \& Csete, M. (2015). Sustainability Indicators in Assessing Urban Transport Systems. Periodica Polytechnica Transportation Engineering, 43. 138-145. https://doi.org/10.3311/PPtr.7825

[13] Dobranskyte-Niskota, A., Perujo, A., \& Jensen, P. (2009). Indicators to Assess Sustainability of Transport Activities Part 2. European Commission - Joint Research Centre. https://publications.jrc.ec.europa.eu/repository/bitstream/JRC 54971/sust_transp_ind_report_final.pdf

[14] Ishizaka, A. \& Labib, A. (2009). Analytic Hierarchy Process and Expert Choice: Benefits and Limitations. OR Insight, 22(4), 201-220. https://doi.org/10.1057/ori.2009.10

[15] European Environment Agency. (2016). Transitions towards a more sustainable mobility system. TERM 2016, EEA Report no. 34/2016. https://eionet.kormany.hu/download/c/e7/a1000/ TERM_2016_THAL16034ENN.pdf

[16] Litman, T. (2016). Well Measured: Developing Indicators for Sustainable and Livable Transport Planning. Victoria, BC, CA : Victoria Transport Policy Institute

[17] Nathan, H. S. K. \& Reddy, B. S. (2011). Urban Transport Sustainability Indicators - Application of Multi-view Black-box (MVBB) framework. Indira Gandhi Institute of Development Research, Mumbai. http://www.igidr.ac.in/pdf/publication/ WP-2011-022.pdf

[18] Kjosevski, S., Kochov, A., Kostikj, A., \& Danev, D. (2017). Sustainable development of road transport through introduction of electric vehicles - initial study for developing regions. The $1^{\text {st }}$ International Conference towards Sustainable Development (TSD'2017), University Mother Teresa, Skopje, 27-28 October 2017. 
[19] Kubáňková, M., Hyršlová, J., \& Becková, H. (2015). Indicator Systems for Measuring and Monitoring Sustainability of Transport. The $9^{\text {th }}$ International Days of Statistics and Economics, Prague, September 10-12, 2015.

[20] Eisenhammerová, M. (2016). Sustainable Transport Indicators. Perner's Contacts, 11(4), 13-22.

[21] Litman, T. \& Burwell, D. (2006) Issues in sustainable transportation. International Journal of Global Environmental Issues, 6(4), 331-347. https://doi.org/10.1504//JGENVI.2006.010889

[22] Huang, Y., Ng, E. C. Y., Zhou, J., \& Surawski, N. (2018). Ecodriving technology for sustainable road transport: A review. Renewable and Sustainable Energy Reviews, 93, 596-609. https://doi.org/10.1016/j.rser.2018.05.030

\section{Authors' contacts:}

Stevan Kjosevski, PhD, Assistant Professor

(Corresponding author)

University "Mother Teresa" in Skopje,

Faculty of Technical Sciences,

Republic of North Macedonia, 1000 Skopje, Mirche Acev No. 4

Tel: +389 23161004

E-mail: stevan.kjosevski@unt.edu.mk

Atanas Kochov, PhD, Professor

Ss. Cyril and Methodius University in Skopje,

Faculty of Mechanical Engineering,

Republic of North Macedonia, 1000 Skopje, Karpos II bb

Tel: + 38923099200

E-mail: atanas.kochov@mf.edu.mk

Darko Danev, PhD, Professor

Ss. Cyril and Methodius University in Skopje,

Faculty of Mechanical Engineering,

Republic of North Macedonia, 1000 Skopje, Karpos II bb

Tel: + 38923099200

E-mail: darko.danev@mf.edu.mk

Aleksandar Kostikj, PhD, Associate Professor

Ss. Cyril and Methodius University in Skopje,

Faculty of Mechanical Engineering,

Republic of North Macedonia, 1000 Skopje, Karpos II bb

Tel: + 38923099200

E-mail: aleksandar.kostikj@mf.edu.mk 